ON THE PROWL 



\section{ON THE PROWL}

In Search of Big Cat Origins

MARK HALLETT AND JOHN M. HARRIS

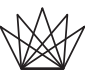

COLUMBIA UNIVERSITY PRESS

New York 
Columbia University Press

Publishers Since 1893

New York Chichester, West Sussex

cup.columbia.edu

Copyright @ 92020 Columbia University Press

All rights reserved

Library of Congress Cataloging-in-Publication Data

Names: Hallett, Mark, 1947- author. | Harris, John Michael, author.

Title: On the prowl : in search of big cat origins / Mark Hallett and John M. Harris.

Description: New York : Columbia University Press, [2020] |

Includes bibliographical references and index.

Identifiers: LCCN 2019034905 (print) | LCCN 2019034906 (ebook) |

ISBN 9780231184502 (hardcover)| ISBN 9780231545525 (ebook)

Subjects: LCSH: Panthera-Evolution. | Panthera-Origin.

Classification: LCC QL737.C23 H3326 2020 (print) |

LCC QL737.C23 (ebook) | DDC 599.75/5-dc23

LC record available at https://1ccn.loc.gov/2019034905

LC ebook record available at https://lccn.loc.gov/2019034906

Columbia University Press books are printed on permanent and durable acid-free paper.

Printed in the United States of America

Jacket art: On the mammoth steppe of the Trans-Caucasus Range of western Russia, a pride of Eurasian steppe lions (Panthera spelaea spelaea) begins an early morning hunt for reindeer or bison.

Cover design: Milenda Nan Ok Lee

Cover art: Mark Hallett 
In memory of Dr. Alan Rabinowitz, whose sacrifices and hard work in understanding the biology of jaguars and other wild cats has provided hope for their continuance on Earth, and of Cathy McNassor, who never met a cat she couldn't bond with 

The lions pass a thornbush and melt.

Though the whole day is unbroken

the passage of the sun will represent heaven the bones will represent time.

-Josephine Jacobsen

I feel

the link of nature draw me: flesh of flesh, Bone of my bone thou art, and from thy state Mine shall never be parted, bliss or woe.

-John Milton 
